\title{
A História das Mulheres e as representações do feminino na história
}

\author{
História das mulheres e as \\ representações do feminino.
}

TEDESCHI, Losandro Antonio.

Campinas: Curt Nimuendajú, 2008. $144 \mathrm{p}$.

Nas últimas décadas do século $X X, a$ história sofreu grandes transformações teóricas e metodológicas que direcionaram os olhares dos historiadores a temas e grupos sociais que, até então, estavam à margem dos estudos históricos, como as mulheres, os velhos, os operários, os camponeses e os escravos. Daí a história das mulheres emerge como um campo de estudo, influenciada pelos novos interesses da disciplina histórica e pelas campanhas feministas. Os reflexos dessas renovações não demoraram a alcançar o Brasil, e o aumento dos estudos sobre as mulheres nos programas de graduação e pós-graduação fez com que a história das mulheres se consolidasse rapidamente em nosso país.

Dentro desse contexto, o livro História das mulheres e as representações do feminino, de Losandro Antonio Tedeschi, publicado em 2008 pela editora Curt Nimuendajú, é mais uma contribuição aos que se ocupam em entender as mulheres na história. $O$ autor, atualmente professor da Universidade Federal da Grande Dourados - UFGD, onde atua no curso de graduação e pós-graduação em História, tem ampla experiência nesse tema, fruto de seus estudos de mestrado e doutorado, bem como de sua atuação junto a organizações como o Movimento de Mulheres Trabalhadoras Rurais MMTR e a Red de Educación Popular entre Mujeres de America Latina - REPEM.

O livro, dividido em três capítulos, busca, pela análise dos discursos filosófico-religiosos, compreender como em diferentes momentos históricos a sociedade enxergava o comportamento feminino e criava representações para as mulheres. Eram discursos legitimadores da inferioridade "natural" das mulheres. Nas palavras do próprio autor,
Esses discursos recorrentes exerceram influência decisiva na elaboração de códigos, leis e normas de conduta, justificando a situação de inferioridade em que o sexo feminino foi colocado [...] Assim, a desigualdade de gênero passa a ter um caráter universal, construído e reconstruído numa teia de significados produzidos por vários discursos, como a filosofia, a religião, e educação, o direito, etc. perpetuando-se através da história, e legitimando-se sob seu tempo (p. 123).

Nessa perspectiva, Tedeschi utiliza-se das articulações entre história e gênero para demonstrar as inter-relações socialmente construídas entre os sexos. Sobre os estudos de gênero, o autor adverte serem importantes, na medida em que possibilitam a análise "das relações entre os sexos, buscando principalmente contribuir para os estudos sobre a condição feminina e a vida familiar na sociedade" (p. 10). Nesse sentido, o autor apresenta importantes considerações sobre os estudos de gênero na atualidade, mostrando os ganhos obtidos com essa nova abordagem histórica, que trouxe consigo "uma diversidade de documentações, uma teia de novos sentidos e significados, e requerem uma paciente busca de indícios, sinais e sintomas, uma leitura detalhada para descortinar a história das mulheres" (p. 11).

No primeiro capítulo - "História das mulheres: abordagens" -, como o próprio título evoca, o autor faz um breve apanhado sobre a história das mulheres, bem como sobre as diferentes abordagens da moderna historiografia, que perpassam essa área do conhecimento histórico, tais como imaginário, sexualidade, corpo, trabalho, relações de poder, relações de gênero, dominação simbólica, práticas discursivas, religiosidade, relações sociais, vida econômica e representações. Nesse sentido, a história cultural da maneira como é trabalhada por Roger Chartier mereceu especial destaque por parte do autor, que analisou formulações discutidas por esse historiador sobre a importância da representação para o entendimento do universo cultural, destacando os benefícios de se estudar a história das mulheres pelas representações: "Ao abordar a história das mulheres pelas representações, busca-se trazer para o cenário 
os discursos de construção das identidades e da interpretação masculina do mundo. Cabe então a nós, homens e mulheres, contribuir para desnaturalizar essa história" (p. 40).

O segundo capítulo, intitulado "Representações do feminino", busca analisar, segundo o autor, "a construção históricofilosófica dos vários discursos que em certa época conferiram um caráter científico e natural aos papéis da mulher, do que significa ser mulher" (p. 12). Para tanto, Tedeschi elegeu dois discursos fundamentais para a compreensão das primeiras representações construídas na história sobre o feminino: o discurso de matriz filosófica grega e o discurso da moral cristã no mundo medieval.

No discurso de matriz filosófica grega, o autor destaca o olhar masculino da teoria filosófica, que pensava a mulher como um objeto, ou seja, "criaturas irracionais, sem pensar próprio", que deveriam viver sob o controle dos homens. Representações estas que, segundo o autor, é possível perceber no pensamento filósofo de Platão, Aristóteles e Hipócrates, que, por meio de um discurso masculino sobre o corpo feminino, construíram mitos que justificavam a inferioridade e a fragilidade feminina.

Quanto às representações femininas presentes no discurso da moral católica, o autor ressalta que o modelo judaico-cristão exerceu influência significativa na definição do lugar ocupado pela mulher na Igreja, na sociedade e na cultura ocidental, não restando dúvidas de que esse discurso foi fundamental para reforçar as desigualdades de gênero. Ao buscar os modelos do feminino veiculados e defendidos pela Igreja Católica, Tedeschi identifica dois "paradigmas do feminino" que procuram enquadrar a percepção social das mulheres para a criação de seus modelos de autorrepresentação. Tais paradigmas são representados por duas mulheres centrais na tradição cristã, "Eva pecadora" e "Maria virtuosa", que, devido às suas características antagônicas, são utilizadas pelo cristianismo para representar todo o universo feminino.

No terceiro e último capítulo - "A confluência dos saberes: as representações e os espaços sociais das mulheres" -, o autor se propõe a "pensar e aprofundar a questão dos lugares e funções, que se constroem pelo casamento e reforçam o ideal de lar e de maternidade - como papéis historicamente construídos e legitimados pela moral cristã" ( $p$. 101). O autor ressalta que os papéis atribuídos à mulher, de mãe e esposa, foram representações que contribuíram para a definição de alteridade e identidade feminina, resultando em práticas culturais que a limitaram ao espaço privado. Tedeschi também trata das representações sociais das mulheres na modernidade, destacando que nesse período o poder patriarcal e a delimitação dos papéis das mulheres no espaço privado não diferiram das representações do feminino observadas na Antiguidade e no Medievo.

Nesse sentido, a leitura da obra História das mulheres e as representações do feminino, de Losandro Antonio Tedeschi, permite ao leitor conhecer e analisar os discursos responsáveis por construir a desigualdade de gênero como "natural", bem como as representações sociais que esses discursos constroem sobre a mulher. Sintético, porém temporalmente abrangente, o livro permite uma visão panorâmica sobre o tema tratado, sendo, dessa maneira, extremamente útil aos estudantes dos cursos de graduação e pós-graduação e aos demais pesquisadores que têm em comum o interesse pela história das mulheres.

\section{Marcilene Nascimento de Farias Universidade Federal da Grande} Dourados 